\title{
Online Religious Radicalism: A Global Proxy Warfare Model in Indonesia
}

\author{
M Affan $^{1}$, A Thohir ${ }^{2}$ \\ UIN Sunan Gunung Djati, Bandung ${ }^{1}$ \\ \{mehmed.affan@gmail.com ${ }^{1}$, ajid.thohir@uinsgd.ac.id ${ }^{2}$ \}
}

\begin{abstract}
The rapid development of information and communication technology, proxy war methods have become easier to apply because proxyforming narratives can be published widely at low cost only through the internet. This has been proven to be run by IS (Islamic State) terror groups that carry out proxy wars throughout the world simply by spreading propaganda narratives of religious radicalism through the internet. Based on such threats, the following article will discuss online religious radicalism as a proxy war model in Indonesia. This study aims to explain how the content of religious radicalism can become a form of global proxy war that threatens Indonesia. The results of this study are expected to contribute ideas in the discourse on radicalism and counter radicalism in a security perspective. The method used in the study is a literature research method both offline and online. From the research conducted, it was concluded that religious radicalism content published online aims to establish a rigid, aggressive and offensive religious understanding of Indonesian Millennial Muslims. With the formation of such understanding, Indonesian Millennial Muslims are directed to become proxies for narrative disseminators in achieving their goals in Indonesia, such as the formation of the Caliphate, the establishment of an Islamic state or running a lone wolf attack. Thus, the presence of religious radicalism on the internet is actually a form of global proxy war against Indonesia.
\end{abstract}

Keywords: online radicalism, proxy war, security threats, Millennial Muslims, Indonesia

\section{Introduction}

The 21 st century tends to be identified as an era of the industrial revolution 4.0 where the use of internet communication networks has played a very important role in various fields of human life. On the other hand, the 21 st Century is also a century of proxy warfare [1, p. 1]. The Yemeni War, the Syrian Civil War and the Crimea War are examples of proxy wars that occurred in this era. In the future, the presence of a proxy war will become increasingly dominant because a proxy war is a cost-effective war that is quite loved. This is increasingly evident by the rapid development of information and communication technology where a model of proxy warfare is applied in cyber mode. An example of a proxy mode cyber-war is hacking and the threat of sophisticated computer viruses [2, pp. 40-44].

However, hacking and sophisticated computer virus attacks, together with terrorism, rebellion movements, roadside bombing, and weapons of mass destruction are sometimes identified as forms of asymmetrical warfare [3, p. 3]. Thus, ambiguity in the use of terms of 
proxy warfare and asymmetrical warfare is still common. The relationship between asymmetrical warfare and proxy warfare is indeed quite close, where proxy warfare as a method of warfare is often born from conflicts that are asymmetrical. In other words, a proxy war can be called a derivative of an asymmetrical war. Regarding this, the IS terrorist group can be used as an example. In the context of warfare, IS is a David who tried to win the war against many Goliaths. The asymmetrical conditions facing IS have pushed them to implement proxy wars throughout the world [4, p. 160].

IS utilizes the sophistication of communication technology to produce a proxy war in a slightly different form from hacking and sophisticated computer attacks. IS did it by spreading propaganda narratives through the internet. The result is lone wolf attacks in various countries, such as in Australia by Man Haron Manis and Numan Haider. In Canada, the action was carried out by Martin Couture-Rouleau and Michael Zehaf - Bibeau. In the United States, it was carried out by Zale Thompson. In France, it was carried out by Bertrand Nzohabonayo. While in Indonesia, it was carried out by Ivan Armadi and Dita's Family [5, pp. 202-209].

Basically, IS propaganda narratives can be identified as narratives of religious radicalism. This kind of narrative is actually not an IS monopoly because the 21 st century-terrorist group itself has been accustomed to using the internet to spread such propaganda messages [6, p. 8]. But, IS becomes the most successful group in carrying it out. This is actually a new model of global proxy war.

In the 2018 Global Terrorism Index, Indonesia was ranked 42. With that ranking, Indonesia is still included in the category of countries with medium impact of terrorism [7, p. 8]. Meanwhile, in the 2019 Global Peace Index, Indonesia is ranked 41 which is included in the category of countries with high levels of peace $[8$, p. 8]. Nevertheless, the potential threat of proxy warfare for online religious narrative models is quite large for Indonesia. This is due to the number of internet users in Indonesia which has reached 171.17 million people from Indonesia's population of 264.16 million. This means that 64.8 percent of Indonesia's population has access to the internet [9]. Thus, the population of Indonesia having the potential to be exposed to online religious radicalism is very large in number.

Departing from the lack of discussion about this kind of proxy war model and the enormous threat to Indonesia, the following article will discuss online religious radicalism as a model of global proxy warfare in Indonesia. This is important to study considering that the proxy war is still a rare study theme in Islamic studies in Indonesia. In addition, the use of proxy wars as research themes is also important in the framework of expanding the subject of study in Islamic studies in Indonesia. The main question in this study is how online religious radicalism can become a global proxy war model for Indonesia. The results of this study are expected to have positive implications as a reference in the policy formulation of religious radicalism deterrence and terrorism prevention in Indonesia.

\section{Method}

The method used in this research is library research method. Sources used are scientific articles on religious radicalism, proxy wars, and IS propaganda magazines.

\section{Result and Discussion}

With people becoming increasingly dependent on the internet, everything has now been forced to go online with the aim of globalization [10]. In this way, the barriers between countries become meaningless. All kinds of information can be received by anyone in any part 
of the earth as long as he is connected to the internet. Likewise with the narrative of religious radicalism that is distributed online. At a certain point, the radical religious narrative can influence the audience to become a proxy ready to carry out actions directed by the actor. The question that arises from this condition is how can a narrative of religious radicalism be a model of a global proxy war?

To answer the question above, IS' propaganda narration can tell us how the radicalism narrative was built as a tool to form a proxy and lead him to take action according to the wishes of the actor. In the IS case, initially the propaganda narrative was packaged in a magazine called Islamic State News (ISN) magazine. However, besides publicizing propaganda through ISN, this terrorist group also has another propaganda magazine that contains IS political reports called Islamic State Report (ISR). Cleverly, IS combines the two for efficiency and effectiveness, so that a propaganda magazine called Dabiq appears. This magazine publishes all military news, government and religious activities IS with the aim of propaganda $[11$, p. 3]. This magazine not only represents IS propaganda, but also publishes visions of the Caliphate [12, p. 459].

In its journey, Dabiq has been published in 15 issues. Starting from the first edition of Dabiq in July 2014 to the 15th edition of Dabiq which was published in July 2016. Compared to other terror group publications such as Al Qaeda, Dabiq is published in a more authoritarian and more religious language [13, p. 13]. When IS occupied territories in Iraq and Syria began to experience heavy attacks from coalition forces, IS stopped the publication of Dabiq. Nevertheless, that does not mean they stop the spread of their propaganda narratives. Instead of Dabiq, IS published a new propaganda magazine called Rumiyah. Through this propaganda magazine, their proxy war continues.

IS itself is currently experiencing a major setback in its occupied territories in Iraq and Syria. Although IS organizationally and territorially have been battered, but the threat of terror from this group continues. This is of course caused by the IS propaganda narratives that are still spread on online virtual networks. Anyone who accesses the internet can download and store it on their device. Unwittingly, they have the potential to be a sleeping proxy of IS. In the future, this sleeping proxy can metamorphose into an active proxy ready to carry out terror throughout the world [5].

In the first edition of Dabiq, IS published the establishment of the Caliphate and called it a new era for Muslims around the world [14, pp. 8-9]. IS then divided the world only into two camps, namely the camp of the faithful and the infidels, where the next message from IS was an invitation for all Muslims in the world to migrate to their occupied territories. IS stated that their struggle to establish the Caliphate aims to overshadow all Muslims in the world [15, pp. $10-11]$.

The first edition of Dabiq was an introduction to the next narrative of radicalism. Here, they introduced themselves to the whole world as a new caliphate that would have authority for all Muslims in the World. But IS has not given any orders other than just inviting Muslims to share in the results of their struggle in Iraq and Syria. The Caliphate has been used as their basic narrative to link their existence with the previous Muslim rulers. The use of the term amir al-mu'minin to refer to their leader has emphasized the effort to establish the legitimacy of power over every Muslim in the world.

In the second edition, IS still used invitations rather than commands. IS is still trying to find support from many Muslims around the world in a slightly persuasive way. The use of the story of Noah Alaihi Salam was made IS as an analogy between them and people outside them. In this way, IS targets the religiosity of Muslims as a persuasion tool [16, p. 5].. 
Muslims who read might be a little influenced by this narration because they will view IS as a very religious group of Muslims.

In the third edition, IS reiterated its invitation to Muslims to migrate by labeling it as a move from hypocrisy to sincerity. The hadith of the Prophet Muhammad (PBUH) and the historical stories of the Prophet (PBUH) have been used as the legitimacy of their invitation in terms of religion. Meanwhile from the worldly side, IS promises material to Muslims who are willing to migrate to their occupied territories. IS promises money and accommodation for every Muslim who migrates to their occupied territories [17, p. 33].

After the first three editions, IS began to build narratives whose purpose is to form a proxy. This was done by building a narrative that the Crusades were taking place. IS put themselves as the representative of the World Muslim Forces while their enemies were as Crusaders. The hadiths giving information about the war during the time of the Prophet Muhammad (PBUH) used as a means of legitimating their actions. At the same time, IS also tried to attract the sympathy of Muslims to support them fighting against the Crusaders [18, p. 10].

The narrative that encouraged the proxy to act was increasingly apparent in the fourth and subsequent editions, where IS called on Muslims around the world to attack citizens who supported the Crusades wherever they were. Every Muslim was even encouraged to kill the crusaders. The killing was labeled IS as a proof of a Muslim's support for IS [19, p. 44]. To reinforce the loyalty of Muslims who have become IS proxies, IS's next narrative stated the illegality of the concept of ethnicity and nation according to the teachings of Islam in all its aspects [20, p. 7]. With this kind of narrative, IS has erased the legitimacy of Muslim citizenship and replaced it with the fake citizenship of the Islamic State.

In order to protect their power from any attacks in the Muslim World itself, IS built a narrative that every effort to fight them was the same as fighting the Caliphate. IS called it as a pagan act [21, p. 50]. Furthermore, IS also spread narratives stating that terrorism is compatible with Islamic teachings. Thus, every statement condemning the act of terrorism IS was a statement of apostasy from a Muslim [22, p. 14].

The narratives mentioned above, basically have their own characteristics. First, make the power as the main goal. The term caliphate or Islamic state is basically just a camouflage to make it look Islamic in Muslim eyes. Second, the use of Islamic teachings as the basis for the legitimacy of their policies and actions is clearly seen. In this way, the target of the investigators they are targeting has become very clear, namely the Muslims. The first point shows the nature of the narrative radicalism of IS. While the second point has shown how religion has been used as camouflage to legitimize these radical actions.

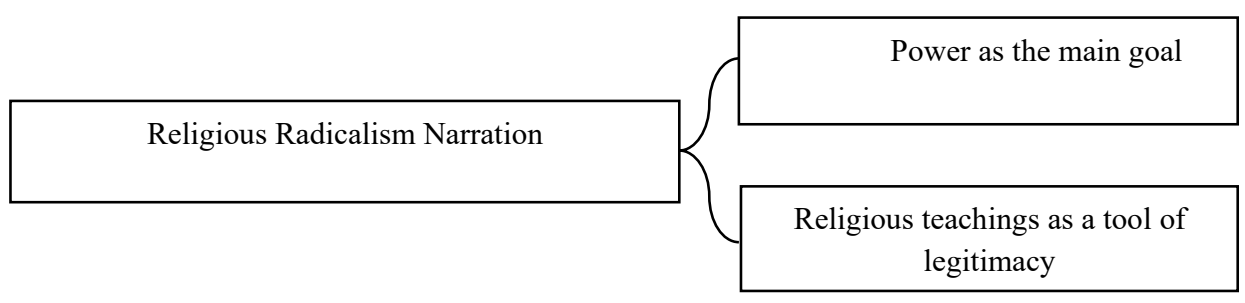

Fig. 1. Basic characteristic of religious radicalism narration 
The two features above are still not enough to make a narrative of religious radicalism as a form of proxy war. The narrative of religious radicalism can only be called as a form of proxy warfare when it has directed its audience to take massive supportive actions towards the actor's goals. In the Dabiq case, this was also clearly seen after the first three editions of Dabiq. What is narrated in Dabiq has succeeded in causing chaos in the form of lone wolf attacks around the world. Thus, the Dabiq narrative model can be an example of a form of online religious radicalism that acts as a new style of proxy war.

Implementation of this kind of proxy war can not only be done by IS, but also by other parties. Such a simple proxy war has made this model as the most dangerous threat to the world. The actors only need to produce a narrative of religious radicalism, then spread it through cyberspace. The product can be in the form of demonstrations, mass riots and rebellions. The product is actually just a way from the actor to achieve his goals by using the hands of others. These actors may take the form of organizations or individuals with an agenda of their respective interests.

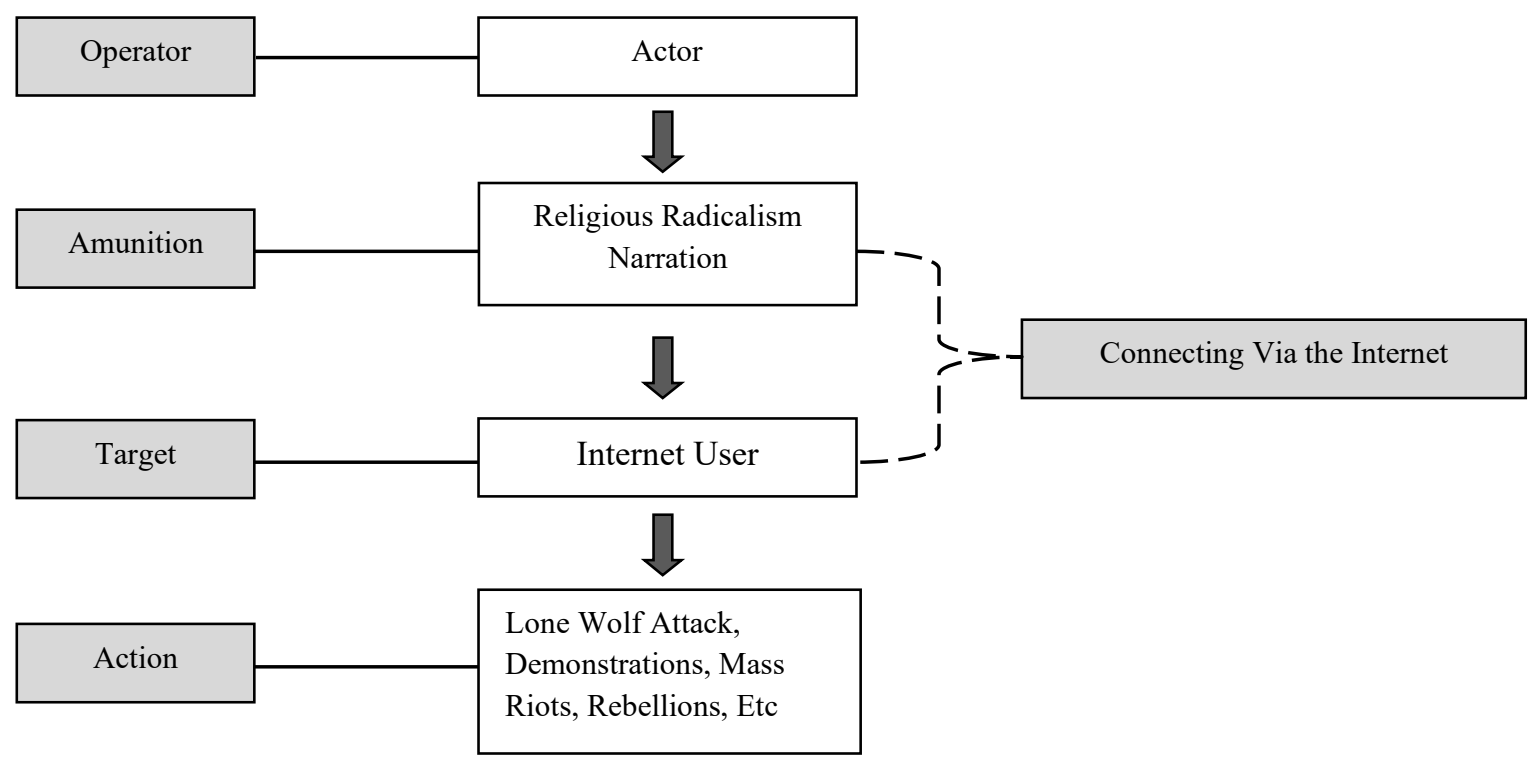

Fig. 2. A proxy war scheme in the online religious radicalism model

The rapid development of information and communication technology has changed the map of the use of this war method. This model proxy war also became possible because of the sophistication of information and communication technology. So, the biggest disruption resulting from the era of the industrial revolution 4.0 was the spread of religious radicalism which could trigger the return of the Crusades in a more dire form. 


\section{Conclusion}

Given that the industrial revolution 4.0 has strengthened world globalization, online religious radicalism as a proxy war model has also been global. Indonesia as a country with a large population of internet users has become a country with a high threat vulnerability. Therefore, this proxy war model has become a real serious threat to Indonesia. Therefore, more comprehensive efforts are needed in order to deal with it.

For Islamic studies in Indonesia, this is a challenge, given that the security aspect is not the object of study in Islamic studies in Indonesia. Even studies on radicalism and terrorism have not made proxy warfare an approach. The role of Muslim scholars in producing parameters that can identify this kind of proxy war is urgently needed. Not only that, counter proxy warfare narratives produced from Islamic studies in Indonesia are also needed to deal with proxy war narratives in the model of online religious radicalism. For this reason, in the future, more studies are needed to make the proxy war as an object and approach in Islamic studies.

\section{References}

[1] J. B. Alterman, "The Age of Proxy Warfare," Middle East Notes and Comment. CSIS Middle East Program, May 2013.

[2] A. Mumford, "Proxy Warfare and the Future of Conflict," The RUSI Journal, vol. 158, no. 2 , pp. 40-46, Apr. 2013.

[3] D. L. Buffaloe and I. of L. W. (Association of the U. S. Army), Defining Asymmetric Warfare. Institute of Land Warfare, Association of the United States Army, 2006.

[4] M. Affan, "Ancaman Dan Tantangan Muslim Indonesia Di Era Perang Proksi," Analisis, vol. 18, no. 2, pp. 147-170, 2018.

[5] M. Affan, "The Threat of IS Proxy Warfare on Indonesian Millennial Muslims," Indonesian Journal of Islam and Muslim Societies, vol. 8, no. 2, p. 199, Dec. 2018.

[6] P. Cornish, D. Livingstone, D. Clemente, and C. Yorke, On Cyber Warfare. London: The Royal Institute of International Affairs, 2010.

[7] Institute for Economics \& Peace, Global Peace Index 2018: Measuring Peace in a Complex World. Sydney: Institute for Economics \& Peace, 2018.

[8] Institute for Economics \& Peace, Global Peace Index 2019: Measuring Peace in a Complex World. Sydney: Institute for Economics \& Peace, 2019.

[9] APJII and Polling Indonesia, "Laporan Survei Penetrasi dan Profil Perilaku Pengguna Internet Indonesia 2018," Asosiasi Penyelenggara Jasa Internet Indonesia (APJII), 2019.

[10] H. K. Gambhir, Dabiq: The Strategic Messaging of the Islamic State. Institute for Study of War, 2014.

[11] H. J. Ingram, “An analysis of Islamic State's Dabiq magazine," Australian Journal of Political Science, vol. 51, no. 3, pp. 458-477, Jul. 2016.

[12] M. Vergani and A.-M. Bliuc, "The Language of New Terrorism: Differences in Psychological Dimensions of Communication in Dabiq and Inspire," Journal of Language and Social Psychology, vol. 37, no. 5, pp. 523-540, Oct. 2018.

[13] Islamic State, "A New Era has Arrived of Might and Dignity for the Muslims," Dabiq, no. 1, pp. 8-9, Jul-2014.

[14] Islamic State, "The World has Divided into Two Camps," Dabiq, no. 1, pp. 10-11, Jul2014. 
[15] A. A. Al Kinani, "It's Either the Islamic State or the Flood," Dabiq, no. 2, pp. 4-5, Jul2014.

[16] Islamic State, "Advice for Those Who Embarking upon Hijrah," Dabiq, no. 3, pp. 3334, Sep-2014.

[17] I. R. Al Hanbali, "My Provision was Placed For Me in the Shade of My Spear," Dabiq, no. 4, pp. 10-13, Oct-2014.

[18] Islamic State, "Rush To Support Your State O Muslim," Dabiq, no. 4, p. 44, Oct-2014.

[19] Islamic State, "The Allies of Al Qa'idah in Sham," Dabiq, no. 8, pp. 7-11, Mar-2018.

[20] Islamic State, "The Law of Allah or the Laws of Men (Is Waging War Against the Khilafah Apostasy?)," Dabiq, no. 10, pp. 50-64, Jul-2015.

[21] Islamic State, "Kill the Imams of Kufr in the West," Dabiq, no. 14, pp. 8-17, Apr-2016. 